\title{
THE ESTABLISHMENT AND DEVELOPMENT OF VIETNAM INDUSTRIAL PARK - SINGAPORE BINH DUONG - SOME EXPERIENCE
}

\author{
D.O.I - 10.51201/Jusst12553 \\ http://doi.org/10.51201/Jusst12553
}

\author{
Dr. Ngo Hong Diep ${ }^{1}$ \& MSc. Nguyen Thi Kim Thoa ${ }^{2}$ \\ ${ }^{1,2}$ Thu Dau Mot University (TDMU), Binh Duong, Vietnam
}

\begin{abstract}
Vietnam - Singapore Industrial Park Binh Duong was established in 1996, is a symbol of friendship and economic cooperation between Vietnam and Singapore. With an approach to dialectical materialism combined with a historical perspective, the article uses historical methods and qualitative analysis on historical causes, the formation and development process of Vietnam - Singapore Industrial Park Binh Duong. With the above analysis, the article gives some comments about the experience from the Vietnam - Singapore Binh Duong industrial park model. The article also discusses the issues: the Vietnam - Singapore industrial park model complements the theory of the Communist Party of Vietnam on socialist-oriented multi-sector economic development; inherit the experiences of Vietnam Singapore industrial park in building this industrial park model in Vietnam; contribution of Vietnam - Singapore industrial park to Binh Duong and make Binh Duong the second Singapore in Asia.
\end{abstract}

Keywords: Vietnam - Singapore industrial park, formation and development, experience, Binh Duong

\section{Introduction}

Binh Duong is a province that has fast speed of industrialization and international economic integration in Vietnam. The authorities of Binh Duong province have brought into play this advantage in the development of industrial zones and economic development of the province, facilitating a strong economic restructuring to shorten the process of industrialization, modernization and international integration of the province. Vietnam - Singapore Industrial Park (Industrial Park) (VSIP) was born in that context.

VSIP Binh Duong Industrial Park is a suitable place for investors to consider long-term stable investment because of favorable factors such as geographical location, favorable soil for the construction of the industrial park. In addition to the above factor, Binh Duong owns a lot of vacant land, good, relatively flat, large-scale land to expand the industrial park when necessary, concentratedly distributed near traffic roads, which have cheap land rental costs, a lot of local labor force; river systems, favorable climate for the development of industrial parks in general.

\section{Literature review}

This research is based on the analysis of the formation and development of VSIP Binh Duong Industrial Park, summarizes the lessons learned and draws valuable experiences in the research on the path of industrialization and modernization of Vietnam and Asia.

The article has applied the model "a swallow in flight" is a sign of development after the economy of the least developed country established economic relations with developed countries by Japanese economist Akamatsu Kaname (Akamatsu, 1962). Because this model has shown Vietnam an important experience to sustain and sustainably develop an industrial economy, especially the construction and development of industrial zones by going in order from the simplicity to the complexity, from stage to stage of the same product gradually improving the product quality, giving priority to the development of supporting industries to 
gradually upgrade to higher industries such as electronics, assembling and manufacturing in order to avoid much dependence on imports, improve technology, quality, and as a result, our products are competitive and participate in international production networks.

At the same time, the article also inherits and develops the model of a joint venture industrial park between Singapore and Indonesia and China, because VSIP is one of the three industrial zones that the Singaporean Government invests in overseas High efficiency: one is Batamindo industrial park in Riau province (Indonesia) built in 1990; the second is Suzhou industrial park in Jiangsu (China), built in 1994 and the third is VSIP in Binh Duong, Vietnam (Pham, 2012).

Thus, it can be understood that the formation of the VSIP industrial park in Binh Duong is a continuation of the success in the cooperation to build IPs of Singapore with the two countries Indonesia and China. More specifically, we can understand that the aforementioned cooperation is part of the foreign policy set by the Singapore Government from the 60s of the twentieth century.

The study also shows that the formation and development of VSIP Binh Duong Industrial Park has made great contributions in many aspects such as enhancing the comprehensive partnership between Vietnam and Singapore; accelerate the process of social modernization and international economic integration of Binh Duong; theoretical and practical experience for the development of VSIP IPs in Vietnam; adding to the theory of the socialist-oriented multi-sector economic development path in Vietnam; In addition, the VSIP Binh Duong model is the factor that makes "Binh Duong become the second Singapore" in Asia in the future.

\section{Research results}

\subsection{Factors forming VSIP Binh Duong industrial park}

Although Singapore and Vietnam are both less affected by the 1997 Asian financial crisis that began in July 1997 in Thailand and the impact on monetary systems, stock markets and asset values. other countries of some Asian countries - but also poses challenges for Vietnam and Singapore, is a factor creating conditions for the two countries to develop and develop cooperation. The above objective factors have influenced the process of forming and developing industrial zones in Vietnam. However, these factors are just "necessary" conditions to create a development environment for Vietnam. In order to successfully develop industrial zones, Vietnam still needs to bring into full play internal factors - ie "sufficient" conditions for industrial zones in Vietnam in general and in Binh Duong in particular to be born and develop sustainably.

In 1990, at the World Economic Forum Conference in Davos, Prime Minister Vo Van Kiet and Prime Minister Ly Quang Dieu laid the foundations of cooperation between Singapore and Vietnam (Ly, 2017: 374). Vietnam - Singapore Binh Duong Industrial Park is the embodiment of the friendship and economic cooperation between Vietnam and Singapore. VSIP Binh Duong was established on the basis of official meetings and dialogues between senior representatives of the two Governments. In March 1994, the Prime Minister of Vietnam (Mr. Vo Van Kiet) made a request to the Prime Minister of Singapore (Mr. Goh Chok Tong) on the establishment of an industrial park of Singapore in Vietnam with the consent of Singapore. In March 1995, after a period of surveying and choosing the location to build, the Singaporean decided to choose Binh Duong province and the Government of Vietnam agreed. Vietnam - Singapore industrial park construction location is located in Binh Hoa, Thuan Giao and An Phu in Thuan An city, Binh Duong province.

With the support from the Governments of Vietnam and Singapore, in December 1995, the Joint Venture Contract was signed under the name Vietnam Singapore Industrial Park Limited Liability Company, the Vietnamese side is Becamex Company contributes 49\%, Singapore side consists of 8 member companies represented by SembCorp Group $51 \%$ 
(Ministry of Planning and Investment, 2006: 2). On the basis of the agreement between the two governments, on February 13, 1996, the Ministry of Planning and Investment granted investment license No. 1498 / GP to establish Vietnam - Singapore Joint Venture Company, unit of constructing and trading infrastructure in industrial zones Vietnam - Singapore and trading the infrastructure of Vietnam - Singapore industrial parks (Huynh Duc Thien, 2019, p.64).

\subsection{Process of formation and development of VSIP Binh Duong Industrial Park}

In 1998, Binh Duong Vietnam - Singapore Industrial Park was formed and put into operation. The investor has completed works such as traffic, water supply system, surface water drainage, wastewater drainage, power generation plant, waste water treatment plant for the whole area, with high quality, modern international standards. At this time, the investment capital for the construction of infrastructure is 45 million USD, reaching $85 \%$ of the total registered capital (of phase I). The construction area is 116 hectares, more than 200 hectares of phase II are completing documents for deployment. In 1999, the area of land for infrastructure construction up to now was 292 hectares, of which 204 hectares for lease for foreign investment, and 61.8 hectares for domestic investment (Ministry Planning and Investment, 1999, p.1).

In 2000, VSIP Binh Duong was recognized as a successful industrial park (with the leased area of 50\%). In 2001, the rate of land rent above reached 129 hectares of phase I (Vietnam Singapore Industrial Park Management Board, 2014, p.1). Up to the beginning of 2003, VSIP leased over $95 \%$ of phase I land and factories (100 ha) and 65\% of phase II land (200 ha), specifically: VSIP Limited Liability Company Binh Duong signed land lease contracts for more than 10 investors with the industrial land for lease reaching 10.8 hectares, bringing the total leased land to 148 hectares (Nguyen, 2003: 2).

After the success of VSIP I Industrial Park, in 2006, VSIP announced the establishment of VSIP II Industrial Park - Binh Duong. Up to now, VSIP II Industrial Park has completed the construction of infrastructure, filling $99 \%$ of the industrial park area, attracting nearly 340 industrial projects with a total investment of about 5 billion USD.

In order to meet the increasing demand for land lease and attract more FDI inflows, in 2018, VSIP's managing unit established VSIP III - Binh Duong with a total area of 1,000 hectares, in Bac Tan Uyen district, Binh Duong. VSIP III is located on Ring Road No. 4, conveniently connected to My Phuoc - Tan Van Street, has a strategic location convenient to connect future investors with Dong Nai and Ba Ria - Vung Tau. Therefore, VSIP III - Binh Duong is expected to soon become a green high-tech industrial park (Minh, 2019).

By 2020, there are 3 VSIP industrial parks in Binh Duong, of which VSIP III Industrial Park has an area of 1,000 ha, investment capital of more than 6,400 billion VND, expected to complete the construction of infrastructure by the end of this year to attract investment projects. In addition, Ascendas has a joint venture with Protrade Company to develop and manage a 500-hectare Protrade International Industrial Park in Binh Duong province (Hong, 2020).

Currently, the major shareholders are Becamex IDC and Sembcorp Development Ltd with capital sources accounting for: Becamex IDC, 49\%; Sembcorp Development Ltd, 40.44\%; Ascendas Investment Pte Ltd, 4.26\%; UOL Overseas Investments Pte Ltd, 2.67\%; MC Development Asia Pte Ltd, 1.89\%; KMP Vietnam Investment Pte Ltd, 1.74\%. As of October 2020, Singapore businesses poured capital into VSIP Binh Duong with a total registered capital of 198 million USD, accounting for $16 \%$ of the total investment capital of Binh Duong province. VSIP Binh Duong mainly attracts and develops strategic and high-tech industries: manufacturing, assembling and car accessories; electricity and electronics; mechanical; textile; pharmaceuticals and healthcare; food and beverage (Doan, 2020). 
Over 20 years of establishment and development, the model of VSIP Industrial Park has always been highly appreciated by Binh Duong. The success of the VSIP brand name has been affirmed and many provinces and cities of Vietnam want to have the VSIP model. Currently, VSIP I - Binh Duong Industrial Park has become one of the model industrial parks with the achievements of a leading industrial park in Vietnam. Covered 100\%, VSIP I has attracted 231 projects with a total investment of about 3.2 billion USD. VSIP I also created 95,000 jobs for workers and contributed to the industrialization, modernization and urbanization of Binh Duong. VSIP Binh Duong has been and continues to fulfill its mission as a "link" between the Government and people of Vietnam and Singapore. Regarding investment, in 2019, the total foreign investment capital registered in the province reached 2 billion 424 million USD, up $81 \%$ over the same period in 2018, exceeding $73 \%$ of the target in 2018. Accumulated to date Binh Duong province has 3,674 projects granted valid investment certificates with a total capital of 33.7 billion USD. The industrial index of 9 months in 2019 is estimated to increase by $9.12 \%$ over the same period. Especially, export turnover continues to grow, up to now, Binh Duong's products have been exported to 88 countries and territories. Export value is estimated at 19 billion 767 million USD, up 13.2\% over the same period in 2018... (Minh, 2019).

With the above policy and a long-term cooperation process since the 90 s of the twentieth century. By 2004, Vietnam and Singapore signed the "Joint Declaration on the Comprehensive Cooperation Framework in the 21st Century", creating a legal basis and favorable conditions to promote the friendship and multifaceted cooperation between the two countries in the future. Therefore, the cooperation and development of VSIP Binh Duong is a good achievement in the foreign policy implementation of both Vietnam and Singapore. The establishment of a strategic partnership framework, a comprehensive partnership between Vietnam and Singapore is the "catalyst" to further strengthen the role and position of VSIP Binh Duong in particular and VSIP in the country in general, connect Vietnam and Singapore.

In addition, VSIP Binh Duong creates great economic and social values, contributing to transforming the industrial economy, restructuring the economy, shortening the process of industrialization, modernization and international integration of Binh Duong province. The development of industrial parks, economic zones in general, Vietnam - Singapore industrial parks in Binh Duong in particular, Not only contributing to the creation of industrial value but also making an important contribution to the creation of a lot of export turnover value, contributing to the State budget, creating jobs, creating demand for the development of many industries, creating a new, modern, long-term value infrastructure system, contribute to modernising infrastructure system of Binh Duong economy. Singapore-Vietnam Industrial Park has the following forms of leasing with flexible payment methods under the agreement: Land lease, ready-built factory rental $\left(1,000 \mathrm{~m}^{2}, 2,000 \mathrm{~m}^{2}\right)$. Regarding the structure of manufacturing industries, Vietnam - Singapore Industrial Park mainly attracts investors to produce fields with relatively high technology content, clean industries including: pharmaceutical, food, electrical / electronic components, precision engineering, high-end building materials, chemicals for basic construction, high-end consumer goods, auto parts, leather shoes, sewing wear, supporting industries such as precision molds, packaging for export goods, printing, cosmetics

Singapore-Vietnam Industrial Park builds and develops an industrial park with complete infrastructure and support services to attract clean and high-tech industries for export and domestic use. The goal of VSIP Binh Duong is to take care of customers and provide customers with quality services; modern infrastructure according to international standards (Singapore standard); The utility center provides support services such as banks, forwarding 
services, medical centers, post offices, shops, office machine maintenance and repair services, especially cafeterias for workers.

The major contribution of VSIP Binh Duong is to build and complete the infrastructure, the electrical system of the Industrial Park is built quite modernly and synchronously right from the ground leveling and road construction, ensure electricity is always ready to be supplied to the enterprise fence, the entire power system in phase $\mathrm{I}$ is underground, contributing to the landscape of the industrial park. Vietnam - Singapore Industrial Park has its own thermal power plant built right after the commencement of infrastructure construction The Industrial Park ensures 24/24 electricity supply to businesses in the Industrial Park with a capacity of $13 \mathrm{MW}$ (with a total investment of more than 5 million USD) to overcome the shortage of electricity and unstable voltage of the national grid at that time (Nguyen, 2007: 37).

The newly established water source for the Vietnam - Singapore Industrial Park was taken from Thu Dau Mot City water plant with a capacity of 6,000 cubic meters / day / night. During the operation to ensure sufficient supply of water for the increasing needs of businesses, by the end of 2003, the supply water was supplemented from Di An water plant with the current capacity of 45,000 cubic meters / day / night, increasing supply capacity to 51,000 cubic meters / day / night. Fire water system is installed along the internal traffic axis, with the distance between the two pillars is 100m (Nguyen, 2007: 36).

The post and telecommunications system in the industrial park is completely designed, built and installed at the same time as the construction of the infrastructure of the industrial park, including the optical cable system with more than 1,500 lines going underground to the business, ensuring data transmission with broadband (ADSL) 24/24 service for businesses at high speed.

VSIP Binh Duong helps create more than 8,000 people with stable jobs, contributes 15 million VND to 870 thousand VND to the local budget, while according to the report of Binh Duong Industrial Zones Authority, State budget remittances as of August 2000 of enterprises in Binh Duong Industrial Park reached only 4.02 million VND, solving for 27,000 employees (data for all 5 industrial zones: Song Than I, Song Than II, Binh Duong, Dong An, Viet Huong). After 10 years of operation (1997-2017), VSIP Binh Duong contributed to the settlement of 282 thousand workers, paid the provincial budget to 150 million VND. Particularly in 2010, VSIP Binh Duong created jobs for nearly 57 thousand workers, contributing to the budget nearly 57 million VND. After 20 years of development (19972017), as of June 2017, VSIP Binh Duong has solved more than 1000 employees with stable jobs, total investment capital of enterprises reached 155 million USD, equaling $103 \%$ compared to 2016, reaching $51.66 \%$ of the 2017 plan, paying hundreds of million VND to the state budget (Phuong, 2017)

Together with Tan Thuan EPZ, VSIP Binh Duong Industrial Park is one of the successful industrial zones in applying a pilot administrative management model under the "one stop, in place" management mechanism of the Government of Vietnam at this time. The strong attention and support of the Governments of Vietnam and Singapore, central and local agencies and departments, the implementation of the one-stop shop mechanism for administrative procedures,... to shorten time to deal with work, increase productivity and work efficiency. With the motto "The management board is the companion of the business" always creates a friendly communication atmosphere; take care and help businesses enthusiastically; consider the difficulties and problems of enterprises as well, creating a comfortable and trusting atmosphere to help investors invest more strongly in VSIP industrial park. This is an important factor that helps VSIP Binh Duong operate and operate smoothly. In addition, VSIP Binh Duong also has other contributions that contribute to raising the "value" of VSIP Binh Duong to a higher level, reflected clearly through the following: invest in constructing houses for workers, organize periodical free medical examination and 
treatment for workers in the industrial park, sponsoring expenses for returning home to welcome Tet for workers far away, giving Tet gifts to policy families, poor studious students,

\section{3. Some experience}

The success of the VSIP Binh Duong model has left a lot of experience for the development of industrial zones in Vietnam, one of the cross-cutting values of the VSIP Binh Duong model is to place the interests of people, people and sustainable development of the environment. Over 20 years (1997 - 2020) of establishment and development, VSIP Binh Duong Industrial Park has left many experiences such as: synchronous efforts and the will of generations of leaders; consensus of the grassroots political system; cooperation and development between domestic and foreign economic groups; experience the harmonious development between production force and production relations; experience training and attracting resources; to develop spearhead industries and high technology; take advantage of the advantages of political institutions and overcome administrative barriers; build the infrastructure; promote favorable heritages and overcome the weaknesses of a land.

The will and efforts of generations of leaders have pushed up the strategic partnership level of the two countries Vietnam - Singapore, is a great factor for the success of VSIP Binh Duong. That synchronous effort is reflected in the economic development policies of Vietnam and Singapore; Undertakings and policies of the Party and State on industrialization, modernization and international integration; the close relationship between Prime Minister Ly Quang Dieu and Prime Minister Phan Van Khai. Two objective and subjective factors leading to the formation, development and existence of VSIP Binh Duong are "necessary" and "sufficient" conditions for VSIP Binh Duong to thrive and spread like today. VSIP Binh Duong Industrial Park was established on the basis of official meetings and dialogues between senior representatives of the two Governments.

The development experience of VSIP Binh Duong Industrial Park is the initiative and consensus of the grassroots political system to adjust policies and limit legal barriers, synchronous planning and construction of infrastructure to create favorable conditions for businesses to operate and develop in VSIP. Over 20 years of establishment and development, generations of leaders of the Party and the People's Government of Binh Duong province have always agreed on the development of the model of VSIP Binh Duong Industrial Park to become the highlight and pride of the people of Binh Duong in the process of development and international integration. It can be seen that the planning and development of socioeconomic goals of the Party Committee and the People's Government of Binh Duong province in the period 2020 - 2025 with a vision to 2030 demonstrates the proactive and consensus. Planning VSIP Binh Duong Industrial Park becomes a pillar promoting the realization of Smart City of Binh Duong in comparison with Singapore.

The breakthrough in thinking and flexible use of the roles of the economic sectors of the Party Committee and the People's Government of Binh Duong province is an important factor promoting the development of VSIP Binh Duong Industrial Park. Vietnam - Singapore Industrial Park was formed on the basis of a joint venture between Becamex Industrial Development Investment Corporation - One-member limited liability Becamex (Becamex IDC) and Serm Corp (Singapore). Regarding FDI, according to the People's Committee of Binh Duong province, the difference compared to other localities is that the capital flow mainly focus on industrial production, so it has a direct impact on the socio-economic development of Binh Duong province. The Party Committee and the People's Government of Binh Duong province delegated the initiative to Becamex IDC Corporation to cooperate and plan infrastructure for enterprises in VSIP. In addition, Binh Duong province also actively invests and develops operational capacity of Becamex IDC Industrial Development Investment Corporation with the aim of meeting the requirements of major economic groups in the world. Successes in cooperation and harmonious development between economic 
sectors in Binh Duong and major corporations and economic groups in the world over 20 years of establishment and development of VSIP Binh Industrial Park Duong is a lesson for VSIP industrial zones in Vietnam.

Regarding solving the relationship between production force and production relations, over 20 years of establishment and development, businesses, companies and large economic groups in VSIP Binh Duong Industrial Park have many preferential policies for employees. Outstanding among these policies are wages, labor regime, housing and social security issues. As an enterprise, VSIP Binh Duong not only creates economic values that contribute to the transformation of the industrial economic structure of the province, but also creates good human values for the whole society. Specifically: construction of housing for workers; care to support workers' lives, build scholarship funds for poor students, policy families. This proves that, in the development plan, VSIP Binh Duong Industrial Park always focuses on balancing economic development with society, pay special attention to creating common values for the community where the industrial park operates. This is the factor that creates sustainable values for the existence and development of VSIP Binh Duong - the second factor contributes to consolidating and confirming the suitability of the VSIP model with the locality.

Experienced in training and attracting highly qualified human resources, VSIP Binh Duong Industrial Park has formed specific human resource training centers for companies; go from small steps to high-skilled training. In addition, VSIP Industrial Park issued preferential policies and created vocational training scholarships (polytechics) for people in Binh Duong. Comments that the mechanism and policies for training human resources are one of the major contributions of VSIP Binh Duong Industrial Park: "During the development of VSIP, it is impossible to ignore the necessity of training resources. Human. Vietnam-Singapore technical training center is invested in modern teaching machines and facilities. Meet $80 \%$ of the requirements of training workers in all fields for factories in industrial zones. On the other hand, the Industrial Park Management Board sets up regular contact with universities, accepts students for internships, and receives employment requests from factories to arrange arrangements. Granting VSIP scholarships to Binh Duong's children from grade 12 to university with a commitment that after completing their studies, they will return to work in Binh Duong. In addition, the Industrial Park also established an "advisory board" that used employees, invited five directors representing five types of production to advise the Vietnam - Singapore Technical Training Center, which type of training should be trained to match the employment requirements of factories in the industrial park

In terms of attracting investment and developing industries, VSIP Binh Duong Industrial Park aims to develop and attract enterprises operating in clean and high-tech industries, serving for export and domestic consumption, creating provides an outstanding advantage over other industrial zones. VSIP Binh Duong focuses on attracting investment in the following industries: precision engineering - car parts; power electronics; pharmaceuticals - healthcare; food - drink; supporting industries and other industries. Currently, the main economic groups, companies, corporations of VSIP Binh Duong: Becamex IDC, Sembcorp Development Ltd, Ascendas Investment Pte Ltd, UOL Overseas Investments Pte Ltd, MC Development Asia Pte Ltd, KMP Vietnam Investment Pte. Ltd. Besides attracting high quality industrial sectors, VSIP Binh Duong Industrial Park also actively builds and develops in the direction of green industry, protecting the environment. VSIP Binh Duong is a pioneer in the construction of an industrial park with a detailed plan associated with urban development and housing, not only for foreign experts, but more especially housing for workers.

One experience that also makes the model development of VSIP Binh Duong Industrial Park is a breakthrough in administrative procedures reform, always striving to effectively implement the "one door" and "one sign" mechanism. Binh Duong's experiences in institutional and legal reforms and efforts have shown that a standard and high quality 
governance system has been created at all levels. The closer the people are, the more standard it must be. Binh Duong has built a mechanism for cadres fearing the people and the apparatus for the people, clean and strong. VSIP Binh Duong and the People's Government of Binh Duong overcame the characteristic "in the past, officials only feared the Party, were afraid of their superiors, afraid of collectives and agencies, not the people, because people did not have the right to direct supervision, did not have place to speak publicly" (Pham Do Chi, 2019).

The above experiences of VSIP Binh Duong have shown that "Binh Duong will become the second Singapore in Asia", is the use of the dynamics of the political system, and bring into full play the resources and wisdom of Binh Duong people. Experiences from VSIP Binh Duong and the development of Singapore have shown that Binh Duong takes advantage of the aspirations of wealth and dedication of many resident communities today. Binh Duong will take advantage of development and it is not "a lost opportunity" as Ly Quang Dieu's judgment about Vietnam and towards the model of having to choose a leader who is thoughtful and compassionate, and People must be eager to contribute, know how to live a civilized life and respect the laws of Singapore Prime Minister Ly Hien Long (Pham, 2019).

\section{Conclusion}

Over 20 years (1997-2020) of establishment, development and integration, with its position and scale, Singapore-Vietnam Industrial Park has the role of "industrial driving force", is " catalyst "contributes to make the chain of Binh Duong industrial parks become more vibrant, accelerate industrialization, modernization, urbanization is carried out faster, save time, create" power and force " for industrial and urban development in particular, changing the socio-economic structure in Binh Duong in general.

VSIP Binh Duong was born and operated with outstanding achievements in infrastructure, flexible management mechanisms, and favorable investment environment, which have brought about great achievements, contributing to changing the socio-economic environment. Binh Duong Association. As an enterprise, VSIP Binh Duong not only creates economic values that contribute to the transformation of the industrial economic structure of the province, but also creates good human values for the whole society. Specifically: construction of housing for workers; care to support workers' lives, build scholarship funds for poor students, policy families. This proves that, in the development plan, VSIP Binh Duong always focuses on balancing economic development with society, paying special attention to creating common values for the community where the industrial park operates. This is the factor that creates sustainable values for the existence and development of VSIP Binh Duong - the second factor contributes to consolidating and confirming the suitability of the VSIP model with the locality.

Applying the model "The Swallow's Flight", VSIP Binh Duong Industrial Park has shown an important experience to sustain and develop the industrial economy, especially the construction and development of industrial zones by follow the order from the simple to the complex, from one stage to another of the same product gradually improve product quality, giving priority to the development of supporting industries to gradually upgrade. Higher industries such as electronics, assembly, and manufacturing to avoid heavy dependence on imports, improve technology, quality and as a result, their products are competitive and participate in international production network. The process of formation and development of VSIP Binh Duong Industrial Park has made great contributions in many aspects such as enhancing the comprehensive partnership between Vietnam and Singapore; accelerate the process of social modernization and international economic integration of Binh Duong; theoretical and practical experience for the development of VSIP IPs in Vietnam; adding to the theory of the socialist-oriented multi-sector economic development path in Vietnam; In addition, the VSIP Binh Duong model is the factor that makes "Binh Duong become the second Singapore" in Asia in the future. 


\section{References}

[1] Akamatsu, K. (1962). "Historical pattern of economic growth in developing countries". The Developing Economic, NO 1, pp 3-25

[2] Vietnam - Singapore Industrial Park Management Board. (2014). Report summarizing the operation situation in 2014 and orientation and tasks in 2015 of the industrial zone in Vietnam Singapore. Binh Duong.

[3] Ministry of Planning and Investment. (1999). VSIP Management Board Report 1999. Hanoi

[4] Ministry of Planning and Investment. (2006). VSIP Management Board Report 2006. Hanoi

[5] Doan, T. (2020). Vietnam - Singapore Industrial Park. Electronic information portal of Binh Duong province. Retrieved from https://www.binhduong.gov.vn/dautuphattrien/Lists/KhuCumCongNghiep/ChiTiet.aspx?ID=166\&Cat egoryId=Khu\%20c\%C3\%B4ng\%20nghi\%E1\%BB\%87p\&InitialTabId=Ribbon.Read

[6] Ly, Q. D. (2017). Ly Quang Dieu's memoir from the Third World to the First, the Saigonbook translation team. National Political Publishing House-Truth.

[7] Minh, K. (2019). Vietnam - Singapore industrial park attracts more than 8.5 billion USD of FDI. Industry and Trade. Retrieved from https://congthuong.vn/khu-cong-nghiep-viet-nam-singaporethu-hut-hon-85-ty-usd-fdi-126544.html

[8] Nguyen, V. L. (2007). Solution to complete the operating model of Vietnam-Singapore industrial zones to contribute to attracting investment in Binh Duong province. Master thesis, University of Economics, Ho Chi Minh City.

[9] Nguyen, V. V. (2003). Vietnam - Singapore leading industrial park in the country. Binh Duong Newspaper.

[10] Pham, D. C. (2019). Making Saigon into Singapore only needs a dream of 20 years. Retrieved from https://www.bbc.com/vietnamese/forum-47278863

[11] Pham, T. N. T. (2012). History of Vietnam - Singapore Relations (1965-2005). Publisher. General Ho Chi Minh City.

[12] Phuong, L. (2017). The VSIP model not only creates the VSIP IP, but also creates a model for other industrial zones to learn. Binh Duong Newspaper, No. 5086, dated June 13, 2017.

[13] Trong, D, (2006). Some initial experiences of Vietnam - Singapore Industrial Park. People's Newspaper. Retrieved from https://nhandan.com.vn/chuyen-lam-an/M\%E1\%BB\%99ts\%E1\%BB\%91-kinh-nghi\%E1\%BB\%87m-b\%C6\%BO \% E1\% BB\% 9Bc-\% C4\% 91\% E1\% BA\% A7u-c\% E1\% BB\% A7a-KCN-Vi\% E1\% BB\% 87t-South --- Singapore-505935 /, October 22 / 2020. 